Northwestern University School of Law Northwestern University School of Law Scholarly Commons

Faculty Working Papers

2009

\title{
THE EUROPEAN COURT'S POLITICAL POWER ACROSS TIME AND SPACE
}

Karen Alter

Northwestern University School of Law, kalter@northwestern.edu

\section{Repository Citation}

Alter, Karen, "THE EUROPEAN COURT'S POLITICAL POWER ACROSS TIME AND SPACE" (2009). Faculty Working Papers. Paper 175.

http://scholarlycommons.law.northwestern.edu/facultyworkingpapers/175

This Working Paper is brought to you for free and open access by Northwestern University School of Law Scholarly Commons. It has been accepted for inclusion in Faculty Working Papers by an authorized administrator of Northwestern University School of Law Scholarly Commons. 


\title{
The European Court's Political Power Across Time And Space
}

\author{
By Karen J. Alter, Northwestern University \\ Forthcoming in Revue française de science politique (Vol 59, 2009)
}

Most work on the European Court of Justice (ECJ) builds on two seminal studies that documented how the ECJ helped transform the European legal system. In 1981, Eric Stein published 'Lawyers, Judges and the Making of a Transnational Constitution' revealing how collectively the ECJ jurisprudence transformed an international treaty into a constitution for Europe. Joseph Weiler expanded Stein's analysis in his 1991 classic The Transformation of Europe, showing how the ECJ's constitutional doctrines stretched existing legal practices and 'closed exit' by making it harder for member states to escape their legal obligations through their own creative interpretations or via non-compliance. Stein's and Weiler's accounts remain uncontested classics, providing incontrovertible evidence that the ECJ did use creative legal interpretations to establish for the ECJ a broader role in European politics. But we need to go beyond their accounts. Stein and Weiler do not ask "why did litigants and national judges invite the ECJ to render its audacious decisions?" Moreover, the narratives provided by Stein and Weiler draw on conceptions of the power of courts that implicitly suggest any court could do as the ECJ did — interpret its mandate broadly so as to construct the building blocs of its capacious influence and authority.

Subsequent research has revealed significant variations in the political influence of the ECJ, based in large part on varied demand for legal enforcement of European rules. The variation in itself raise questions. Why would the ECJ be an audacious and/or influential political actor only over some issues and in some contexts? The question then becomes "what political and social factors make it possible for courts to build their legal and political authority?" My research on the ECJ uses variation in the ECJ's influence over time and space to understand how the political and social context contributes to the influence of the ECJ.

This article is adapted from the introduction and conclusion of my new book The European Court's Political Power (Oxford: Oxford University Press, 2009), which brings together 15 years of my articles and book chapters regarding the European Court of Justice's political role in European politics. The introduction and conclusion pull out a common narrative from extensively researched chapters that focus on different pieces and parts of the ECJ's history. The common story told across analyses is that the ECJ gains influence by allying with societal actors within states to encourage greater respect for European rules. The larger volume shows that societal actors do not always choose to draw the ECJ into their campaigns. Also, the ECJ's agency matters - the ECJ at times chooses to play a minimalist role, interpreting law narrowly and even illogically when there is little social support for the law it is asked to apply. The analysis suggests that factors exogenous to the ECJ, activation by others and the presence of societal actors who share the ECJ's substantive objectives, are the largest factors shaping the role the 
ECJ plays. The larger book embeds this narrative across issues and cases so that we can see what makes societal actors want to work with the ECJ, and vice versa.

My interest in the ECJ's experience has always been to understand the possibilities for international courts (ICs) and international law more generally. Even if a reader does not share this interest, however, I think they will find that they understand the European experience better through comparing the ECJ to other ICs. The ECJ was from inception an unusual international court. The ECJ had a unique design: member states could not opt out of the ECJ's authority, and non-state actors (the High Authority/Commission and private actors) were authorized to initiate suits and even to seize the ECJ to challenge member state policy. European integration also arguably had broader aspirations, compared to the United Nations for example. The concept 'supranational' was created to capture these usual qualities. But what were once unique attributes of the ECJ are no longer so.

Today most IC designs are closer to the design of Europe's supranational courts than they are to the design of the International Court of Justice. Most ICs have compulsory jurisdiction and non-state actors are allowed to initiate disputes against state and international actors (Alter 2006). There are also many other international institutions with broad aspirations, and thus many other ICs that have been delegated the same types of authority the ECJ has. ${ }^{1}$ In other words, there are more ICs with the ECJ's design and official authority to be powerful political actors. Yet almost none of these other ICs have replicated the ECJ's experience.

Observing these trends, I conducted extensive research on the case which comes closest to resembling the ECJ. The Andean Tribunal of Justice (ATJ) is the ECJ's jurisdictional clone. It was created in 1984, and modeled explicitly on the European Court of Justice (Keener 1987); it shares the preliminary ruling system of the European legal system, and it also has a foundational treaty (the Cartagena Agreement) which lays out a structure for creating a common market and allows for Andean rules to create direct internal effects within national systems. ${ }^{2}$ The ATJ has extensively mimicked the ECJ. It had a foundational period much like the ECJ's foundational period (discussed by Weiler, 1991), during which it declared the supremacy and direct effect of Andean law, using identical terms to the ECJ (indeed it both replicated and cited key foundational ECJ legal decisions). ${ }^{3}$ The ATJ also has had cases to adjudication; with over 1400 decisions to date it is the third most active international court-less active than the European Court of Justice and the European Court of Human Rights, but more

\footnotetext{
${ }^{1}$ In fact over half of operating ICs have been delegated an enforcement role where a supranational prosecutor is empowered to raise cases against state actors (11 out of 20), forty percent (8 out of 20) have been delegated an administrative review role where the IC can review the validity of decisions of supranational administrative actors and in some cases of national implementation of supranational rules, and at least five, possibly seven, international courts have been delegated explicit constitutional review roles including the power to invalidate supranational legislation and in some cases the power to review the compatibility of international rules with domestic policy (Alter 2008: 62).

${ }^{2}$ Note that in 1996 the ATJ court treaty was revised, so Keener's analysis of the substantive jurisdiction of the ATJ is outdated.

${ }^{3}$ I discuss these developments in an article that is not yet complete: (Alter and Helfer Manuscript in progress)
} 
than twice as busy as the International Court of Justice, the World Trade Organization's dispute resolution body, the Inter-American Court of Human rights and the International Criminal Court combined! Most of the ATJ's docket comes via national court references, and the ATJ has replicated the ECJ's ability to influence policy. But its influence pertains to a single substantive domain - intellectual property disputes (Helfer, Alter, and Guerzovich 2009). For other areas of law, the ATJ lacks a fundamental demand for activist decisions, and the ATJ demurs from purposeful interpretations that could be helpful to the litigants. The contrast between the ATJ and the ECJ led me back to Europe, forcing me to reexamine what I thought I understood about the European legal system.

There are of course a number of exceptional elements that set the ECJ apart from other ICs. The European Union has far more secondary legislation than does any other international institution, which contributes to the broader range of issues litigated (Stone Sweet 2004: 58-64). The extent of legislation and litigation suggests that in Europe supranational and domestic politics are more intertwined (Cichowski 2007). But this was not always so. Stein's and Weiler's analysis are so intriguing because the ECJ laid the foundations for its political authority at a time when there was not much secondary legislation nor great political support for the objectives of building a common market. In a similar context the ATJ followed the ECJ's early constitutionalization of the legal system, but it refused to use the Andean legal system as a tool to force market integration (Saldias 2007).

In short, it is now clear that the differences in the design of the ECJ cannot explain why the ECJ was so successful compared to other ICs, nor can the extent of ECJ legislation explain early differences between the ECJ and the European Court of Human Rights, and other ICs. Where some would therefore say that the ECJ is sui generis, for me these exceptional qualities simply call for explanation. I see the ECJ as representing the far end of the continuum of influence for an international court - the ECJ is about the most powerful and influential international court that is realistically possible. I tend to view limits to the ECJ's power and influence as 'normal'-general limitations that even the most powerful courts face. This does not mean that I expect all international courts to follow the ECJ's trajectory. Rather I believe that if we can unlock why the ECJ is so successful, we can then understand better the challenges that limit the influence and political power of other international courts. And, if we can understand the limits of the ECJ, we can adjust our expectations - we can figure out what limits are inherent to even the most independent and powerful courts (after all, every actor faces limits), and what limits are specific for a particular court or particular political system. As a by-product, we will understand the European Court of Justice's own history better.

It is in this context that I set about drawing together and reflecting on my work on the European Court of Justice. This essay draws from the analyses in my 2009 book to identify the larger factors shaping European Community legal politics across time and space. The book's individual chapters reveal the fuller story, and they more adequately reference the scholarship of others.

Part I of this essay focuses on the early history of the European Court of Justice - when the ECJ was both a typically ineffective international court in some 
ways, and exceptionally activist and influential court in other ways. It adds to wellknown accounts of the ECJ's transformation of the European legal system a comparison of the ECJ in the context of the ECSC (from 1951-2002), and an analysis of the role of transnational jurist advocacy movements in promoting early European legal integration. It then summarizes my argument of how the ECJ induced national courts and national governments to support the transformation of the European legal system. By the end of Part I, we have the ECJ of today - a constitutional court for Europe in all but name, with the supremacy and direct effect of European law, and national courts as willing enforcers of ECJ jurisprudence. Part II focuses on factors that generate variation in the influence of this court on European politics and policy. In this essay, these ideas are asserted. The reader should look to my 2009 book for evidence and citations to support the claims. Part III speculates on why the ECJ has been such an exceptional international court. Part IV concludes by identifying an agenda for further research on the ECJ.

\section{Rethinking the European Court of Justice During the Founding Period of Legal Integration (1952-80)}

The first part of the book divides according to issues and actors the foundational period during which the ECJ's authority was built. Here I mainly summarize the key findings thereby identifying the constituent parts that contributed to the ECJ's early success. The discussion is mostly a roadmap of where to look for the fuller explanations the book provides.

The ECJ's early history introduces a theoretically tantalizing juxtaposition. Through pretty much the entire 50-year history of the European Coal and Steel Community (ECSC), the ECJ was both timid and ineffectual at compelling compliance with ECSC rules, let alone in facilitating political or policy change. But at the same time that the ECJ of the ECSC was doing very little (1960s and 1970s), the ECJ was bold and assertive in constitutionalizing the European Community Treaty to create a quasi-federal legal order. I argue that a distinct set of social forces emerged in the 1960 s, which allowed the ECJ to be so bold in the context of the early European Economic Community (EEC). I then investigate how the ECJ co-opted national judges and national governments into its project of constitutionalizing the European legal system.

In an essay entitled The Theory and Reality of the European Coal and Steel Community (with David Steinberg) I analyzed the 50-year history of Europe's Coal and Steel Community, which was established in $1951{ }^{4}$ The analysis confirms what others have also found. Haas was right that the ECSC achieved many of its formal goals during its early history, including the elimination of tariffs and quotas. But in fact there were no tariffs or quotas protecting European coal and steel markets at the time, thus the achievement was purely formal and symbolic. We followed the ECSC's role up until 2002 , finding that until the 1980s the ECSC as an institution had little influence over how European coal and steel sectors developed and adapted to changes in the

\footnotetext{
${ }^{4}$ This essay is reprinted as Chapter 3 of my 2009 book.
} 
international political economy, in large part because its institutions were sidelined and its rules were never fully implemented. (In the 1980s the ECSC became the chosen forum used by states to shut down their big steel industries, a policy choice that was reluctantly forced on states by international market developments.)

This analysis challenges a central claim about the early period of European legal integration. A common view is that the ECJ is most expansionist in its interpretations when the political process is blocked (Weiler 1981). But in the context of the ECSC, the political process was blocked and the ECJ was not expansionist. The reality that the ECSC for so long had little political influence begs the question: Why was the ECSC of so little substantive import? Why were ECSC rules barely if at all enforced? What does the very limited role played by the ECJ in this history tell us about the dynamics shaping law and politics in the European Union?

You will have to read the analysis for the fuller story, but the gist of the analysis is that the reason ECSC rules were ignored is that governments, firms, and workers had little interest in actually building a common market in coal and steel, thus the High Authority and the ECJ lacked social and political support. We argue that there were benefits to be gained by enforcing ECSC rules, but states did not want to dismantle the true barriers to free trade - the cartels, subsidies, differential transportation rates, and manipulative market practices (e.g. deviating from published prices and delivering extra goods), which ensured that steel markets remained nationally segmented. Steel industries also preferred national help over ECSC help. As a result, Europe's coal and steel policy remained nationally defined until the mid 1980s.

A logical question to ask is if states did not want a common market, why did they create the ECSC in the first place? The larger essay answers this question, but then argues that even after the ECSC lost its initial purpose, the ECSC did not lack an economic or political basis to proceed. There were still benefits to be had, and litigants who could benefit from the enforcement of ECSC rules. The ECJ could have also been a more forceful actor, providing purposeful interpretations instead of using technicalities to avoid issuing decisions of substance. But firms understood labor unions' desires to create and hold high paid jobs in the coal and steel sectors. European governments and economic actors were also convinced by the conventional wisdom of the day that having a national steel industry was key for industrial development and national security. European governments repeatedly aided ailing national coal and steel industries in the 1950s, 1960s, and 1970s, holding for themselves the political benefits associated with strong government intervention in the economy. Meanwhile those actors who might have gained from a more integrated European coal and steel industry eschewed the potential advantages of using litigation to promote their economic advantage. Knowing that ECSC rules lacked any real domestic political support, the ECJ refrained from aggressively interpreting and enforcing ECSC rules in the cases that were brought.

What does this experience tell us about the political role of the ECJ? The ECSC had the most muscular and innovative international enforcement mechanism that existed at the time (Levi 1976: 70-71). Some ECSC cases did reach the ECJ in the 1950s and 1960s, but these cases either did not ask or failed to remedy states' general non- 
compliance with ECSC rules. It is worth returning to Stuart Scheingold's truly excellent book about this period. Scheingold has investigated every ECJ decision with respect to the ECSC (up until 1965 when the book was published) and found cases where the litigants settled out of court. Scheingold argues that the ECJ and litigants were responding to the High Authority's fundamental weakness. A closer look at Scheingold's cases suggests that private litigants were quite willing to challenge High Authority actions that they did not like; the ECJ responded by ensuring that the High Authority stuck close to its legal mandate. Yet ECJ judges must have surmised the lack of political or societal support for ECSC rules, and for building a common market in coal and steel more generally. ${ }^{5}$

An interesting juxtaposition that The Theory and Reality of the European Coal and Steel Community did not explore is that the ECSC was floundering at the exact same moment in time when the EEC's legal system was taking off. ${ }^{6}$ Scheingold published his analysis of the ECSC rule of law in 1965-after the ECJ's activist 1962 Van Gend and 1964 Costa v. Enel rulings. Scheingold found signs that the ECJ was working to build a rule of law, but it was a fairly limited and technical rule of law. While Scheingold found no evidence of the ECJ yielding to government pressure, he found a number of examples where the ECJ used technical rulings to avoid controversy. In these cases, Scheingold argued, the ECJ largely avoided making decisions of substance. Scheingold concluded from these examples that political tools to control the ECJ, including the short tenure of ECJ judges, appeared to be fairly effective in limiting ECJ activism (Scheingold 1965: 34). My larger body of work also found that the ECJ in the 1960s avoided making decisions with a substantive impact, so as to avoid provoking a political response (See Alter 1998 reprinted in the 2009 volume). But an important difference is that the ECJ was doctrinally bold in the context of the EEC, issuing rulings that clearly were not the intention of national governments. Why was the ECJ a typically timid and fairly ineffectual international court in the ECSC context while simultaneously an audacious international court in the EEC context? In neither context did member states seem to actually want to build a common market, at least not in the 1960s.

In an essay entitled Jurist Advocacy Movements in Europe: The Role of EuroLaw Associations in European Integration (1953-1975) I offer an answer to this question by reconstructing the efforts of nationally based Euro-law associations to use legal means to promote a political agenda that was being thwarted by Charles de Gaulle and his supporters. ${ }^{7}$ The analysis compares the role of Euro-law associations to the Andean experience where there have been no associations supporting the Andean Tribunal of Justice. The comparison helps underscore how much the ECJ benefited

\footnotetext{
${ }^{5}$ Parenthetically, although Weiler's analysis should travel to the Andean context (e.g. the ATJ's authority should have become more broadly recognized; the ATJ should have helped to close exist), Scheingold's analysis is a far better fit for explaining the Andean Tribunal's experience.

${ }^{6}$ Ironically, just as Haas' Uniting of Europe was published, France, Germany, and Italy blocked the High Authority's efforts to invoke its exceptional powers to deal with a crisis in the coal sector. From 19581965, European governments made a number of important decisions that basically ensured that an integrated coal and steel market under supranational authority would not emerge.

${ }^{7}$ The analysis appears for the first time as chapter 4 of the 2009 book.
} 
from having an ideologically driven kitchen cabinet of support, ${ }^{8}$ and how helpful it was that association members included politically well placed individuals who could use their offices (as legal counsels, judges, scholars, and government officials) to aid the ECJ's constitutionalization project.

This revisionist account of the orchestration behind the ECJ's constitutionalization process reinforces what the focus on the ECSC had also foundself-interested actors do not spontaneously arise to promote market integration. Activist litigants and judges need to be inspired by more than narrow self interest - they need to believe that their interest serves a larger social purpose. Without this shared sense, either litigants will not raise provocative cases and/or judges will not reward litigants with far-reaching rulings. The result will either be a very limited jurisprudence, one that is neither expansionist nor transformative, like the ECJ's jurisprudence in the context of the ECSC. Or, there may even be a negative feedback effect where narrow rulings undermine litigant incentives, limiting the extent to which actors seek to use international courts to enforce international rules (as has occurred in the Andean context).

Of course Euro-law associations were pro-integration in the first place. In English we say that they were the "choir" the ECJ was preaching too. For the ECJ to succeed in its endeavor, it had to convince people who were not already part of the ECJ's choir. My 2001 book sought to explain how national judges and governments were co-opted into the ECJ's project.

While most national legal systems did not accept the ECJ's argument that the "special nature" of the Treaty of Rome and the European legal system implied the supremacy of European law, national judiciaries in all member states have found ways to accommodate the supremacy of European law. My 2009 book includes my earlier article which makes it very clear that there were compelling legal and political reasons, argued strongly by national judges, to reject the ECJ's supremacy doctrine. ${ }^{9}$ I suggest that member states' highest national courts were most antagonistic to the ECJ's supremacy doctrine, because the supremacy doctrine was more threatening to their own institutional independence and authority. For lower courts, I argued, the ECJ offered a choice. By appealing to EC law and the ECJ, lower courts could circumvent doctrinal obstacles created by higher courts. They could also simply not consult the ECJ, which they were not legally required to do, and even challenge ECJ decisions sending a contrary interpretation up for appeal. High courts could also use EC law to circumvent national legal barriers. Or, they could avoid the ECJ and even challenge its authority.

My book Establishing the Supremacy of European Law (2001) shows how contestation across higher and lower courts, and across branches of within national legal

\footnotetext{
${ }^{8}$ The American term "kitchen cabinet" refers to President Andrew Jackson's practice of circumventing his real cabinet (the one approved by the Senate) to instead plan policy with like-minded friends. National governments are arguably the ECJ's statutory cabinet, since they write the laws the ECJ is interpreting. Euro-law associations were the ECJ's kitchen cabinet, providing a means for European officials to test out ideas and seek informal advice, which was especially important given that in the 1960s national political leaders were challenging the supranational aspects of European integration.

${ }^{9}$ The article is reprinted as Chapter 5 of my 2009 book.
} 
systems, shifted the terrain from under the most antagonistic national courts. While there were national judges and national courts that clearly wanted to limit the ECJ's authority and power, these judges were unable to stop others from turning to the European legal system. Intransigence vis-à-vis ECJ jurisprudence lost all influence and affect in a context where other national courts were inviting the ECJ to issue interpretively expansionist legal rulings, and where these national judges were bringing ECJ doctrine and ECJ rulings into national legal systems. Also, the actions of prointegration national judges, and national judges who simply followed what EC law required, exposed the fallacy of the arguments of intransigent national judges.

Opponents of European law supremacy had argued that European and national law did not allow for the supremacy of European law, and they suggested that granting European law supremacy would create a politically untenable situation. Over time it became very clear that a number of national courts found legal means to accommodate ECJ jurisprudence, and their actions did not provoke a political rebuke. Increasingly, the claims of recalcitrant national judges looked both implausible and out of sync with the larger legal and political trends of the time (See Alter 2001 for more).

The second group of actors who had to be co-opted were national governments. In a 1998 article $^{10}$ I argued that the transformation of the European legal system by the ECJ limited the possible responses of national governments to its decisions within the domestic political realm. In the early years of the EU legal system, national politicians turned to extralegal means to circumvent unwanted decisions; they asserted the illegitimacy of the decisions in a battle for political legitimacy at home, instructed national administrations and national judges to ignore ECJ jurisprudence, or interpreted away any difference between EC law and national policy. The threat that national governments might turn to these extralegal means, disobeying an ECJ decision, helped contain ECJ activism. With national courts enforcing ECJ jurisprudence against their own governments, however, many of these extralegal avenues no longer worked. Because of national judicial support for ECJ jurisprudence, national governments were forced to frame their response in terms that could persuade a legal audience, and thus they became constrained by the legal rules of the game. The larger essay also considers why member states have not used their other tools to influence the ECJ-they have not restricted the ECJ's jurisdictional mandate or tampered with the ECJ through the appointments process. I explain this paradox, providing evidence of a pattern where states are unable to reign in ECJ excesses, but they do "learn" which leads them to write European rules more carefully and circumscribe future delegations.

As a collection, the analyses I undertake in my 2009 book suggest much more contingency about the European experience than is often presumed. While located in Europe, in a sea of liberal states, the ECJ can also suffer from having a fragile legal authority. Indeed the ECJ, like all courts, must strive to stay in sync with larger societal interests - which is not to say that it must kowtow to the preferences of governments in power. A number of factors came together in the 1960s to give the ECJ the social support it needed to be more interpretively expansionist. The essays in this special edition help document these factors.

${ }^{10}$ Republished as Chapter 5 of my 2001 book, and chapter 6 of my 2009 book. 
The question then becomes what accounts for the varied influence of the ECJ across time and space. The next section turns to this question.

\section{The ECJ and its Varied Influence on European Policy and Politics (1980-2005)}

The chapters in Part II of my book try to understand when and how the ECJ comes to politically influence particular outcomes. The ECJ needs more than a latent social support; to exert influence it needs to be activated by litigants and to have its legal pronouncements picked up by those actors who want its jurisprudence respected. What factors influence where and when interlocutors - litigants, judges, and the implementers of ECJ rulings - embrace ECJ interpretations and the power of the European legal system? What shapes when and where ECJ doctrine expands, when and where European law penetrates national legal orders, and when and where the ECJ comes to decisively influence national policy?

There are four steps - thresholds of activation of the European legal system-each of which needs to be surmounted in order for a litigation strategy to be employed. These thresholds each generate sources of variation in the ECJ's opportunity and ability to be a politically influential actor. For European level litigation to influence national policy: 1) there must be a point of European law to draw on; 2) litigants must seize on a litigation strategy as a means to promote their objective; 3) national courts and the ECJ must be willing to issue favorable rulings that support their objective; 4) there must be political follow-through - a post-ruling political mobilization that shows political actors (governments, firms) that there will be continued and mounting costs to maintaining an illegal policy. Research has revealed a number of factors that shape each step. Here I briefly summarize the analysis from the book and the literature, providing a general overview of where we stand in understanding variation in where and when the ECJ comes to influence legal debates:

Threshold 1: Enforceable law and the ECJ's willingness to be a political player within a policy domain

There has to be law that can be invoked by litigants. For most areas of European law, every member state surmounts the first threshold, since the EC law applies in all member states. EC law is mostly concerned with economic issues with a transnational dimension, but the EU has jurisdiction in some national policy areas (such as agriculture, value-added tax, and external trade); these are the areas of national policy most likely to be affected by EU litigation.

Simply having the law is not enough. The ECJ also has to be willing to interpret the law in ways that reward litigant efforts. Scholars have suggested that the ECJ is more likely to rule against a national policy in areas where ECJ doctrine is well developed than where it is not (Garrett, Kelemen, and Schulz 1998), when the material and political costs of the legal decision are relatively low (Conant 2002), when there is no political consensus against the ECJ's decision among member states (Maduro 1998), or when public opinion supports enforcement of the European rule (Carrubba and Murrah 2005; Caldeira and Gibson 1995). These suggestions come more from theory 
than empirical investigation. While scholars have attempted to explain ECJ decisionmaking across cases (Kilroy 1999), so far no one has been able to link ECJ decisionmaking to any set of factors - such as the political power of states, or public opinion on a policy area. 11

Social science approaches have thus far largely failed to explain the decisionmaking of the ECJ (e.g. when the ECJ will rule against states, or be an expansionist law-maker), or of any international court for that matter. ${ }^{12}$ The best we can say is that it is clearly not true that the ECJ seizes every opportunity to aggrandize its power. The ECJ is constrained by a few factors. The law itself provides a constraint. Also, the ECJ hesitates to insert itself in polycentric contexts (e.g. where there are many centers of authority and control). ${ }^{13}$ We can also say that the ECJ is most likely to be assertive when European law is very clear, and when the issue touches on its own powers and prerogatives. The ECJ also clearly looks for a set of sub-state actors that prefer EU law enforcement, and it considers the positions of the majority of states on an issue (Maduro 1998). I used the short-hand of social support to capture these factors.

\section{Threshold 2: Interested litigants}

Given the central role of litigants in bringing the ICs into policy debates, much of my work has focused on explaining litigant mobilization. Neo-functionalist theory has largely assumed that self-interested actors will present themselves, using the legal system to promote their case whenever it is profitable (e.g. when the political benefits exceed the costs of litigation, and when better routes to achieve their goal are not present). But if we consider the many cases that are not pursued, it becomes clear that narrow self-interest (e.g. the possibility of profiting through litigation) is neither necessary nor sufficient for potential plaintiffs to emerge.

The European Commission knows that litigants will not self-organize. The Commission has actively sought out interlocutors so as to build a constituency that might support its efforts. In the area of equal pay, for example, Elaine Vogel Polsky, a former European official, first published an article where she suggested that European

\footnotetext{
${ }^{11}$ Most scholars use as a dependant variable national court references to the ECJ, not ECJ decision-making (Stone Sweet 1999; Carrubba and Murrah 2005). Bernadette Kilroy's study is an exception, but her study does not adequately control for alternative explanations, and she is unable to find support for her key hypothesis - that the ECJ bends to the political will of powerful states. For a discussion of Kilroy's analysis, see: (Pollack 2003). Qualitative studies have been able to conclude that the ECJ is not bending to the preferences of states (as argued before the ECJ), and that the ECJ tends to be a purposeful interpreter of European law (Stone Sweet 2004; Cichowski 2007), but these studies tend focus on issue areas where it is known that the ECJ is a purposive interpreter of the rules (Stone and Cichowski look at the environment as a control case). As far as I know, no one has systematically examined ECJ decision-making across a variety of issue areas.

${ }^{12}$ Erik Voeten's work on judicial voting in the ECHR is a notable exception, though Voeten is focused more on how individual judges behave than on the ECHR overall (Voeten Forthcoming 2008).

${ }^{13}$ The ECJ has refused to become involved in enforcing WTO law (see Chapter 10 in my 2009 book). The ECJ has, however, recently taken on a role overseeing implementation of UN Security Council directives. See: the Kadi decision (joined cases C 402/05 and 415/05) available at: http://curia.europa.eu/jurisp/cgibin/form.pl?lang $=$ en $\&$ Submit $=$ Rechercher\&alldocs $=$ alldocs $\& d o c j=$ docj\&docop $=$ docop\&docor $=$ docor\&do cjo $=$ docjo $\&$ numaff $=C-402 / 05 \&$ datefs $=\&$ datefe $=\&$ nomusuel $=\&$ domaine $=\&$ mots $=\&$ resmax $=100$
} 
law could be a tool to dismantle national policies that contributed to gender discrimination (Vogel-Polsky 1967). When no case raising the issue appeared, VogelPolsky went in search of a litigant. Her test case, Defrenne v. Sabena, established the direct effect of European gender equality provisions. ${ }^{14}$ Vogel-Polsky then wrote articles suggesting that the Defrenne ruling could be generalized to other gender equality cases (Vogel-Polsky 1985; Harlow and Rawlings 1992: 283). The Commission took up where Vogel-Polsky left off, working to disseminate information about the ECJ's equality rulings. The Commission also sought to mobilize actors in other member states to follow the British strategy. It held conferences for equality actors to exchange information, published 'how to' guides on pursuing gender discrimination cases, and conducted the studies I drew on in a study on variation in equal pay litigation across member states. ${ }^{15}$

Rachel Cichowski identified another way the Commission helps to organize groups. The Commission uses its power to propose legislation to mobilize domestic actors, and to keep previously mobilized actors interested in European Union politics. A key contribution of Cichowski's work is that she connects litigation based strategies to a legislation based strategy, showing the feedback effects across the legal and policymaking domains (Cichowski 2007).

What factors explain variation in the willingness of groups to organize around European initiatives? Carol Harlow and Richard Rawlings develop a rather vague notion of how the "goodness of fit" between European law and domestic law shapes whether domestic actors organize to exert Pressure through Law (Harlow and Rawlings 1992). My work has sought to identify the factors that contribute to a goodness of fit. A number of conjectures can be stated in a general way.

Political commitments to the larger objectives the rules represent: Legal victories can reveal the disjuncture between government's formal commitments and its actual practice (Risse, Ropp, and Sikkink 1999: 23-25). Litigants are more likely to mobilize around a litigation strategy where there is deep social commitment to objectives the rules promote, because judges are more likely to reward litigant efforts in such cases and because a legal ruling will be more embarrassing for the government. Where governments and public opinion appears uninterested in the larger objectives (e.g. building a common market in coal and steel), litigants are more likely to be perceived as narrowly self-interested and judges are less likely to issue far-reaching decisions because they will lack broader social support for their rulings. Thus political support for the rules themselves, and the objectives the rules promote, increases the chance of litigant mobilization.

The way collective actors (movements, interest groups, etc) are organized shapes whether litigation is an attractive strategy: In a study on variation in equal pay litigation across Europe we found that in certain countries women's groups saw promoting equal pay and equal treatment for men and women as a key objective, while in other countries women's groups focused more on family matters or on how women

\footnotetext{
${ }^{14}$ Defrenne v. Sabena [1976] I.C.R. 547; Defrenne v. Société Anonyme Belge de Navigation Aérienne Sabena [1978] E.C.R. 1365,ECJ.

${ }^{15}$ Originally published as (Alter and Vargas 2000). Reprinted as chapter 8 of my 2009 book.
} 
can mix work with their familial obligations. These different constructions of the "problems" faced by women led to different strategies when it came to using law as a policy tool (Alter, 2009: Chapter 7).

Examining studies on different litigation rates, we drew a number of conclusions: Litigation is often a tool of the weak, used because actors cannot use the political system to address their concerns. Groups excluded from the political process are more likely to turn to litigation compared to groups with privileged political access. More narrowly focused groups are more likely to turn to litigation strategies. Thus national variations in how group mandates are defined (broad versus narrow mandates), who is part of a group (broad versus narrow constituencies), and the type of access the group has to policy-makers will shape whether litigation is embraced as a tool of political influence (See chapter 9 of my 2009 book for more hypotheses).

\section{Threshold 3: National Judicial Support}

Quantitative studies have sought to explain variation in national reference rates to the European Court of Justice. The best quantitative study to date, authored by Clifford Carruba and Lacey Murrah (Carrubba and Murrah 2005), moves beyond the rather simplistic assertion that trade levels among states translate directly into references to the ECJ. While helpful in the aggregate, such studies are not really helpful to litigants because they do not predict the likelihood that a litigant's case will be referred to the ECJ. ${ }^{16}$ Where litigants can forum shop, they are more likely to be able to find a sympathetic judge. Where litigants are unable to seek out judges, however, institutional factors within a legal system can shape the likelihood of a reference to the ECJ.

Domestic rules of standing present one potential barrier-if litigants are deemed to lack legal standing, their case will never be referred to the ECJ. Variation in the standing of unions and interest groups in raising cases was one factor accounting for the variation in equal pay litigation across European states (Fitzpatrick, Gregory, and Szyszczak 1993: Chapter 5).

Predilections of judges can also present barriers. For example, the French Conseil d'Etat has been historically reluctant to refer cases to the ECJ (Alter, 2001: 138-57). ${ }^{17}$ In Britain, Employment Appeals Tribunals were historically hostile to equal pay claims (Alter and Vargas 2000). Jonathan Golub also found British courts reluctant to refer cases involving environmental issues (Golub 1995). These predilections come from policy preferences (e.g. political leanings) and the social background (e.g. the training and professional background of judges, and institutional histories of courts) of judges, thus they are systematic as opposed to idiosyncratic. These predilections do reveal themselves quantitatively, but they are less easily tested through regression studies, and perhaps for this reason they are seldom investigated. Judicial predilections

\footnotetext{
${ }^{16}$ For example, Carrubba and Murrah find that legal traditions (whether a country is monist or dualist, whether there is a tradition of judicial review) and public opinion shape the prevalence of references. But it is still true that a litigant can procure a reference to the ECJ from within a country where unfavorable traditions or public opinion exists.

${ }^{17}$ French authors have explained this reluctance based on the recruitment system; members of the Conseil d'Etat are trained with future government officials, and they themselves float in and out of government (Radamaker 1988).
} 
make the difference for a litigant who is seeking to use the European legal system to shift domestic policy.

\section{Threshold 4: Political follow-through}

Legal pronouncements are rarely the end of the story. Where national courts will enforce legal rulings, and where government actors want to comply with legal rulings, we can expect fairly automatic compliance with legal rulings. Broader policy shifts are usually a result of post-ruling politics where the costs of maintaining contradictory policies are revealed.

Group mobilization v. individual private actor mobilization: Individual litigants are likely to be satisfied with a legal remedy that applies just to them. Cases where group actors are mobilized are more likely to have an amplified political impact because group members encourage each other to be bold and activist, and because groups are better able to follow legal victories with political strategies - advertising legal victories, finding copycat cases, and showing governments the cost of maintaining illegal policies. Sometimes groups seize on to cases that were raised by unaffiliated private actors. Also, because groups often lack standing, and because legal narratives play better when there is an actual person involved, often members of groups shed their affiliation for the purpose of raising a legal case. But unless a group actor (an institution, powerful state, or an NGO) mobilizes behind a legal ruling, the ruling is unlikely to have broad political impact.

\section{The Four Thresholds Taken Together}

Clearly these thresholds are related in that factors that positively affect one threshold are also likely to positively affect the other thresholds. In other words, where there is social support for the rules, legal rules are more likely to be clearer, litigants are more likely to mobilize to legally enforce the rules, and judges are more likely to reward litigant efforts. The reason to separate them, however, is because individual factors at each step can also derail legal integration. Even where there is social support for certain outcomes, groups may not mobilize around a litigation strategy, judges (national and supranational) may refuse to decide the case in ways that reward litigant efforts, or there may be no follow-through on a legal decisions to generate a more amplified political affect to the ruling. Also, the reasons a threshold may not be surmounted may also have little to do with factors related to European integration. Rather, national institutional variations can translate into systematic variations in the penetration of European law into national systems, and in the appeal to using the European legal system as a tool of political change.

What do these conclusions mean in terms of the political power of the ECJ? Courts are generally tipping point political actors. Where there are powerful actors on both sides of an issue, but governments have for whatever reason privileged an arguably less law-compliant outcome, courts can be invoked by one side to tip the balance in the opposite direction. Courts are more likely to be invoked where there are organized interests that support the rules in question. Also, courts are more likely to be willing to 
aid groups in achieving their agenda when the law in question is extremely clear, and when their legal authority is both exclusive and clear.

Intervening politically is risky. Judges generally will not substitute their own interpretations for politically constructed outcomes where the political terrain is a minefield sown with intensely held deeply divided political beliefs (which can manifest in public opinion measures), and where their own bases of legitimacy are weak. Courts are also hesitant to intervene in highly complex polycentric environments, especially if their own authority is likely to be undercut by other authoritative actors operating in the same terrain.

\section{Lessons from the ECJ experience}

Variation in ECJ influence may be the norm, but we still have the reality that the ECJ is perhaps the most politically influential international court in the world. The ECJ's experience in constructing the basis of its own authority is probably more similar to what domestic constitutional courts have done to build their authority than what international courts tend to do. Yet, the ECJ clearly started out as an international court. Its authority was based on an international treaty. While integration activists hoped integration would erode national commitments, member states and national judges in the early period of European integration (1950-1980), and arguably even today, clearly approached the EEC and the ECJ as an international institution. What could explain why the EC experience has been so exceptional? What is so unique about Europe that its supranational courts have come to have such significant political roles?

The ECJ had a number of factors in its favor. Europe's legal fields were more developed than legal fields in many other countries, which is to say that there is greater political prestige accorded to legal actors in Europe, and well developed traditions and structures that could be fairly easily adapted to the cause of legal integration. ${ }^{18}$ The European integration project was also not simply a collection of economic or functionally beneficial agreements. Rather, a fervent set of actors saw European integration as part of a larger political endeavor of building peace in Europe, united under a rule of law so as to limit any return to authoritarian practices. These factors were important in the history of Europe, but they provide only part of the story. The Euro-law movement was committed and active, but small. How were the vast majority of actors not committed to the European integration as a social or economic project brought along in support of the ECJ's constitutionalization project? Also, there are other contexts where the legal profession has extensive legal fields, and where legal actors are ideologically committed to international legal strategies. ${ }^{19}$ Why did a perfect storm of legal and social support come together to facilitate European legal integration?

\footnotetext{
${ }^{18}$ Forming a legal association for a new issue of law was a fairly standard in European states. There was also a tradition of publishing legal briefs, and many outlets for legal briefs. See Alter 2009 Chapter 4 for more.

${ }^{19}$ Organization for Economic Cooperation Development (OECD) countries present obvious examples of countries with developed legal fields. Human rights presents another area where legal fields are organized around legalized strategies: (See Dezalay and Garth 2002; Keck and Sikkink 1998; Sikkink and Lutz 2001).
} 
Part I of this essay discussed how jurist advocacy movements mobilized to support the ECJ in the 1960s, how national judges were co-opted into the ECJ's project of establishing the supremacy of European law within national systems, and how national judicial support contributed to national governments into accepting a fundamental political transformation that ceded important elements of national sovereignty in ways they did not intend, want, or ever really endorse. But this story is also incomplete in that it focuses mainly on explaining the acceptance of European law supremacy by the ECJ's direct interlocutors. It takes for granted that national courts had the power to lend to the ECJ, so that harnessing national courts became an effective political strategy.

I am increasingly coming to believe that the ECJ's story is part of a larger institutional and political evolution wherein courts in Europe have become the political actors of today, capable of ending Italian practices of dividing power among Christian Democratic and Socialist parties so as to exclude the Communist Party from power, capable of stripping Augusto Pinochet's immunity, thus contributing to an international human rights justice cascade that has reverberated around the world (Sikkink and Lutz 2001). Saskia Sassen's work suggests as much (Sassen 2006). She identifies larger global trends, locating the rise of judicial power as part of the rise of the bourgeoisie, and the ascent of liberal democracy as an organizational form of government. She sees judicial authority as further advanced by the rise of executive authority (at the expense of legislative authority), the rise of the administrative state, and the development of a rights based politics. Her explanation surely capture important factors, but her account is underspecified in that these larger changes have occurred in many states which have not replicated the Europe's penchant for embracing supra-national legal authority.

I believe that Europe's particular history of wanting to overcome the legacy of World War II, including the deadly war among neighbors, the judicial collaboration with authoritarian regimes, and the egregious trampling of individual rights, was key in facilitating national transformations, and the ECJ's success. Europe's World War II history mattered in a few ways.

First, Europe's history helped to build the networks behind pro-European jurist advocacy movements. In the late 1940s, European countries were ruled politically by former members of the anti-fascist resistance. Many of these initial political leaders continued in politics, although quite a number ended up with powerful positions but not as political leaders themselves. Those actors who did not themselves stay in government became representatives in international legal negotiations, and they later used their political offices to aid the European integration project (Madsen and Vauchez 2005). It is not unique for opposition politics to create a networked class of actors who become central in building a new polity. It is, however, unusual for law and constitutional development to be so central to the agenda of such actors, and for international law to figure so highly as part of their reformist agenda.

Europe's history also emboldened jurists - lawyers, judges, and legal scholars - as a group. In the 1950s and 1960s European states were expanding their role in national economies. Political liberals and national judges responded by creating checks on political bodies as they expanded their role, though for different reasons. 
Liberals wanted to limit as much as possible government involvement in the economy. They were a constant constituency to challenge state authority, but they did not always or even mostly succeed in their legal efforts. Jurists as a group mainly wanted to ensure that governments' expanded role adhered to the rule of law. Originally, many jurists' conception of what constituted the rule of law was rather limited. It did not include courts conducting constitutional review of national law, and the legal rights protected by courts tended to be more procedural than fundamental in that there were few courts, in even fewer countries, assessing whether constitutional guarantees were adequately respected by the political branches of government. Over time, basic rights became politically important. It is increasingly common for jurists today to frame their discourse and agenda around a 'rights'-based politics, and thus to be part of a vanguard demanding democratic constitutional reforms (Halliday, Karpik, and Feeley 2007: Introduction), but this is a more recent transformation both in Europe and in the larger international context.

Somewhat distinct is that in Europe, jurists were joined in their more narrowly conceived endeavor of promoting the rule of law by civil servants. Under authoritarian rule (and during parts of Europe's history), ideology and political loyalty were key criteria shaping appointment and promotion in civil service positions. European bureaucracies became professionalized in the 1950s and 1960s, meaning that expertise and competence rather than political connections emerged as the basis for appointment and promotion within national administrations. ${ }^{20}$ Civil servants with expertise and competence chafe at political manipulations of rules, and they became a constituency in support of judges rejecting politically inspired interpretations of legal rules. Thus lawyers had actors within the state they could appeal to and work with to help realize their objective of having governments respect the rule of law.

Finally, Europe's experience with World War II fundamentally changed popular attitudes in Europe. European citizens mobilized time and again to demand their government adhere to the democratic objectives they expected. This synergy between the ECJ's objective of building supranational legal checks on supranational political authority and the larger agenda within European states and societies of creating legal checks on political power created a willingness for national judges to work with the ECJ by referring cases involving European law (the interpretation of which was outside of the competence of national judges). Because of European citizens' commitments to many of the ideals embedded into European Community law, because national judges agreed to enforce European laws, and because civil servants were committed to adhering to legal rulings, bringing the ECJ into specific policy debates could be a potent political tool. [This might be a good place to reference other articles in this symposium]

${ }^{20}$ I am indebted to Antoine Vauchez for this insight. 


\section{An Agenda for further research on the ECJ: The Political Determinants of Social Support}

The larger argument I am making is that the ECJ didn't just declare for itself more power. The ECJ was emboldened to issue its audacious legal ruling because it had the active and explicit support of a network of jurists who were aiding its endeavors. These actors helped to shift the national legal terrain from underneath a set of powerful national courts that were not themselves supportive the ECJ's larger project. The ECJ also benefited from a fortuitous set of circumstances. It was building its own authority at the same time as national judiciaries were building their own bases of power. Indeed it is quite likely that the ECJ was able to co-opt national judges because the developments the ECJ was promoting mirrored steps being taken simultaneously by national judiciaries. In other words, it was the developments underway within European states---the growth of judicial power, an emerging commitment to asserting and protecting individual's basic rights, and the growth and professionalization of the administrative state in European countries - that provided the ECJ with willing interlocutors that could be mobilized around the ECJ's project of using legal means to force European states to adhere to their European legal commitments.

What would we need to know to substantiate these speculations? For the European story we would need to know more about the development of post-war national legal institutions, and how legal developments influenced and were influenced by European legal integration. We would also need to know more about how synergies develop. Why do international law-domestic law synergies not develop in other contexts? Why are technical rules sometimes better for promoting international legal integration while in other contexts constitutional norms, like basic rights laws, connect better to domestic agendas? Why, for example, did a synergy develop around enforcing fairly technical European Community rules (an administrative law dynamic) rather than the more far-reaching and politically central tenets of the European Convention on Human Rights (a constitutional law dynamic)? These questions are far from academic since many practioners and scholars are trying to unlock the factors contributing to the creation of a stable and independent domestic rules of law. ${ }^{21}$

In terms of the study of Europe, the empirical and theoretical agenda this argument suggests would be to investigate the development of powerful national legal institutions, which I believe is one of the defining features of post-World War II European politics. The judiciary was one of the many political institutions that had been discredited through collaboration during World War II. Lawyers and politicians realized that significantly different legal structures needed to be created, but they had to work with the stock of lawyers, professors, and judges that existed. It took new generations of lawyers, professors, and judges entering the legal apparatus, and rising into positions of authority for change to occur. Also newly established legal structures - constitutional courts and new administrative systems — needed to build their authority, to create a new reality that scholars could study and explicate, and that legal actors within national legal systems could respond to and emulate. Given how long

${ }^{21}$ For example, see (Hammergren 2007; Maravall and Przeworski 2003; O'Donnell 2004) 
these changes took, it is not surprising that political scientists who focused on European politics in the 1950s, 1960s, 1970s, and even the early 1980s missed what was happening. Legal evolutions became impossible to ignore in the 1990s because judges started successfully challenging the practices of powerful political elites. Now that we now know the end of the story - in the 1990s administrative and legal actors became key contributors to large-scale political changes, and judicial review has emerged as an important force of policy-making and institutional change - we need to go back in time to add courts back into our earlier understandings. There is strong scholarship on the rise of constitutional courts in Europe (see for example Stone Sweet 2000), but less scholarship on larger social and political changes within national bars, judiciaries, and educational systems. ${ }^{22}$ We need to investigate why and how Europe's legal institutions changed in the post-World War II era (and why legal institutions in other contexts did not change in the same way).

Beyond legal institutional changes, we need to investigate how these changes contributed to legal and political developments in Europe. We need to connect, as Francesca Bignami, Rachel Cichowski, and Peter Lindseth are doing, European level changes to national evolutions (Bignami 2005; Lindseth 2005, 2003; Cichowski 2007). And we need to connect legal changes to larger political changes within and across states. We should be able to locate the construction of a legal and administrative European state into the construction of the economy, and into the construction of constitutional democracy, to see how economic and political conditions shaped these developments. Concretely, we should be able to link European legal developments to our understandings about how 'modern capitalism' was built in Europe in the 1950s and 1960s (Shonfield 1969). We should also be able to identify how legal institutions were part of the 'embedded liberal' meta compromise shaping international and European economic systems in the 1960s, 1970s, and early 1980s (Ruggie 1983). We should be able to see how legal institutions were part of Alan Milward's explanation regarding how European integration helped European countries deliver this embedded liberal compromise, and thus how European integration helped resuscitate the political raison d'être of the post-war European state (Milward 1992). We should be better able to link the histories of European Community integration and the growing authority of the European Convention on Human Rights. And we should be better able to understand how institutional developments benefited from the external threat of the cold war, and the unprecedented economic growth and stability in post-war Europe. When we understand these relationships, we will better understand the pushmi-pullyu relationship ${ }^{23}$ between law and politics.

\footnotetext{
${ }^{22}$ When I began my research on the European legal system in the 1990s, it was extremely difficult to find studies about national legal systems. I was forced to draw on a range of studies that were not directly on point. I have not gone back to examine the literature that has since emerged, but my sense is that there still is a dearth of studies by political scientists, historians or sociologists documenting changes in post-war European legal institutions.

${ }^{23}$ The pushmi-pullyu was the name of the two-headed creature connected at the waist in Hugh Lofting's tales of Dr Doolittle. The pushmi-pullyu had heads pointed in opposite directions. In order for the pushmi-pullyu to walk, the two heads had to work together-one had to walk backwards, so the other could go forwards. For law to work it must induce political actors to voluntarily yield, and if they are to
} 
Such understandings are relevant beyond Europe. It has long been recognized that political institutions facilitate economic development. More recently it has been suggested that legal institutions are important for political stability and economic prosperity (Williamson 1990; Maravall and Przeworski 2003; Halliday, Karpik, and Feeley 2007). But it is far from clear how we get to legal institutions that can facilitate economic and political development, and how variation in legal institutions is related to variations we find in cross-national and cross-temporal economic and political development. Post-World War II Europe is a good place to investigate these questions. But I still believe that these questions are best elucidated through comparative analysis. Rule of law movements have been gaining increasing strength outside of Europe. I think it would be most fruitful to examine the European rule of law movement in the 1950s and 1960s alongside movements in other countries that are emerging from authoritarian rule, as this would expose the importance of contextual factors that European focused studies may well simply take for granted.

Equally important is that we move forward intellectually rather than replicate the past. The early study of legal integration was hampered in a number of ways. Archives were closed, and thus we lacked access to some inside information. But scholars also self-censored themselves because legalism was the dominant scholarly approach of European legal scholars, and because scholars of European integration themselves were politically committed to European integration, which led to studies that tended to whitewash the political elements of European legal integration. ${ }^{24}$ Studies that examine both new and old questions of European integration and international law should not simply replicate the past. In other words, we should not extend old studies to new terrains, but rather use new approaches to examine both new and old terrains.

There are many old questions to investigate in the European context, since we know so little about the legal changes in the post-war period. But there are also many new questions to address. In Europe, the end of the Cold War opened the floodgates for EU membership. There is of course a burgeoning literature focusing on how European Union membership affects Central European countries' policy and politics (Vachudová 2005; Schimmelfennig 2003; Jacoby 2004; Kelley 2004). EU enlargement also offers a cornucopia of ways to investigate how domestic legal institutions reform, how external forces influence domestic reform efforts, and how legal authority gets built (or not built). The current generation of scholars has a chance to document how legal institutions are evolving independently from and in relationship to national political reforms, and to investigate if the EU or other external legal obligations (e.g. the Council of Europe, WTO membership) accelerate or are undermined by domestic institutional evolution.

The question of how enlargement affects institutional development in new member states is especially interesting because the latest set of entrants are both

yield, the legal process must take into account deeply felt political concerns even if it leads to outcomes that are poorly reasoned from a legal perspective. This analogy comes from Alter (2002: 120).

${ }^{24}$ For more on the sociology of knowledge regarding European integration, see chapter 2 of the European Court's Political Power (2009). For more on how legalist approaches systematically ignore political factors, see: (Alter 2002) 
emerging from authoritarian rule and seeking to industrialize in ways that can integrate these countries into the global economy. Newer EU members are thus more comparable to domestic polities in other regions of the world (including national courts in the Andean context). One would expect the European Union to again present a case that is located on the far side of a continuum in terms of international factors being likely to shape domestic development. The former Soviet satellite countries have a number of extremely compelling reasons to truly embrace democratic forms of governance and the rule of law-including membership in the EU. Indeed the EU serves as an anchor with common sets of rules and a model of how these rules are meant to be implemented, and nowhere in the world is there an institution as willing or invested in helping domestic reformers as the European Union. Of course there are many counter-forces at work, and while incentives are strong they may not be strong enough. I do not assume the European Union will be highly successful in inducing desired changes in former Soviet satellites, nor is it likely that all or even most changes that occur will be because of EU efforts. Rather, once again we should expect that if the Europeans cannot influence their neighbors, then the EU and other international efforts may be even less likely to influence legal and political development in other regions of the world.

The ultimate objective of such investigations would be to expose how the social and political context of legal actors influences their behavior, and thereby how domestic and international factors $\mathrm{co}=$ mingle to influence the development and influence of law - both national and international. A second objective would be to add law more centrally back into political analyses, to remember that the judiciary is one of the three branches of governments, that law is the chief tool used by governments to govern, and that legal strategies are often the most viable way to promote political change for actors whose access to the levers are political power are blocked.

\section{Bibliography}

Alter, Karen. 2008. Delegating to International Courts: Self-binding vs. Other-binding Delegation. Law and Contemporary Problems 71 (1):37-76.

Alter, Karen J. 1998. Who are the Masters of the Treaty?: European Governments and the European Court of Justice. International Organization 52 (1):125-152. . 2002. Law, Political Science and EU Legal Studies. European Union Politics 3 (1):113-136.

- 2006. Private Litigants and the New International Courts. Comparative Political Studies 39 (1):22-49.

Alter, Karen J., and Laurence Helfer. Manuscript in progress. Nature or Nurture: LawMaking in the European Court of Justice and the Andean Tribunal of Justice.

Alter, Karen J., and Jeannette Vargas. 2000. Explaining Variation in the Use of European Litigation Strategies: EC law and UK Gender Equality Policy. Comparative Political Studies 33 (4):316-346.

Bignami, Francesca. 2005. Creating European Rights: National Values and Supranational Interests. Columbia Journal of European Law 11:241-352. 
Caldeira, Gregory, and James Gibson. 1995. The Legitimacy of the Court of Justice in the European Union: Models of Institutional Support. American Political Science Review 89 (2):356-376.

Carrubba, Clifford J., and Lacey Murrah. 2005. Legal Integration and Use of the Preliminary Ruling Process in the European Union. International Organization 59 (2):399-418.

Cichowski, Rachel. 2007. The European Court and Civil Society: Litigation, Mobilization and Governance. Cambridge: Cambridge University Press.

Conant, Lisa J. 2002. Justice contained: law and politics in the European Union. Ithaca: Cornell University Press.

Dezalay, Yves, and Bryant G. Garth. 2002. The internationalization of palace wars : lawyers, economists, and the contest to transform Latin American states. Chicago, Ill. London: University of Chicago Press.

Fitzpatrick, Barry, Jeanne Gregory, and Erika Szyszczak. 1993. Sex Equality Litigation in the Member States of the European Community, A Comparative Study: Commission of the European Union DG V.

Garrett, Geoffrey, Daniel Kelemen, and Heiner Schulz. 1998. The European Court of Justice, National Governments and Legal Integration in the European Union. International Organization 52 (1):149-176.

Golub, Jonathan. 1995. Rethinking the Role of National Courts in European Integration: A Political Study of British Judicial Discretion, edited by E. U. Institute.

Halliday, Terence C., Lucien Karpik, and Malcolm Feeley. 2007. Fighting for political freedom : comparative studies of the legal complex and political liberalism, Oñati international series in law and society. Oxford ; Portland, Ore.: Hart.

Hammergren, Linn A. 2007. Envisioning reform: improving judicial performance in Latin America. University Park, Pa.: Pennsylvania State University Press.

Harlow, Carol, and Richard Rawlings. 1992. Pressure Through Law. London: Routledge.

Helfer, Laurence, Karen Alter, and Maria Florencia Guerzovich. 2009. Islands of Effective International Law Adjudication: Constructing and Intellectual Property Rule of Law in the Andean Community. American Journal of International Law.

Jacoby, Wade. 2004. The enlargement of the European Union and NATO : ordering from the menu in Central Europe. Cambridge ; New York: Cambridge University Press.

Keck, Margaret E., and Kathryn Sikkink. 1998. Activists beyond borders: advocacy networks in international politics. Ithaca, N.Y.: Cornell University Press.

Keener, E. Barlow. 1987. The Andean Common Market Court of Justice: Its Purpose, Structure, and Future. Emory Journal of International Dispute Resolution 2 (1):37-72.

Kelley, Judith Green. 2004. Ethnic politics in Europe : the power of norms and incentives. Princeton, N.J.: Princeton University Press.

Kilroy, Bernadette. 1999. Integration through Law: ECJ and Governments in the EU, Department of Political Science, UCLA, Los Angeles. 
Levi, Werner. 1976. Law and Politics in the International Society. Beverly Hills: Sage Publications.

Lindseth, Peter. 2003. The Contradictions of Supranationalism: Administrative Governance and Constitutionalization in European Integration Since the 1950s. Loyola of Los Angeles Law Review 37 (2):363-406. . 2005. Always Embedded Administration: The Historical Evolution of Administrative Justice as an Aspect of Modern Governance in The Economy as Polity (, eds., UCL Press 2005). In The Economy as Polity edited by B. S. Christian Joerges, and Peter Wagner. London: UCL Press (RoutledgeCavendish).

Madsen, Mikael Rask, and Antoine Vauchez. 2005. European Constitutionalism at the Cradle. Law and Lawyers in the Construction of a European Political Order (1920-1960). In In Lawyers' Circles. Lawyers and European Legal Integration, edited by A. Jettinghoff and H. Schepel. The Hague: Elzevir Reed.

Maduro, Miguel Poiares. 1998. We the court : the European Court of Justice and the European Economic Constitution : a critical reading of Article 30 of the EC Treaty. Oxford: Hart Publishing.

Maravall, José María, and Adam Przeworski. 2003. Democracy and the Rule of Law. Cambridge: Cambridge University Press.

Milward, Alan. 1992. The European Rescue of the Nation-State. London: Routledge.

O'Donnell, Guillermo. 2004. The Quality of Democracy: Why the Rule of Law Matters. Journal of Democracy 15 (4):32-46.

Pollack, Mark. 2003. The Engines of Integration: Delegation, Agency, and Agency Setting in the European Union. Oxford: Oxford University Press.

Radamaker, Dallis. 1988. The Courts in France. In The Political Role of Law Courts in Modern Democracies, edited by J. Waltman and K. Holland. London: Macmillan Press.

Risse, Thomas, Stephen Ropp, and Kathryn Sikkink. 1999. The Power of Human Rights: International Norms and Domestic Change. Cambridge: Cambridge University Press.

Ruggie, John. 1983. International Regimes, Transactions and Change: Embedded Liberalism in the Postwar Economic Order. In International Regimes, edited by S. Krasner. Ithaca: Cornell University Press.

Saldias, Osvaldo. Supranational Courts as Engines of Disintegration. Frei Universität Berlin 2007 [cited December 2 2007. Available from www.fuberlin.de/polsoz/polwiss/europa/arbeitspapiere/2007-5_Saldias.pdf

Sassen, Saskia. 2006. Territory, authority, rights : from medieval to global assemblages. Princeton, N.J.: Princeton University Press.

Scheingold, Stuart. 1965. The Rule of Law in European Integration. New Haven: Yale University Press.

Schimmelfennig, Frank. 2003. The EU, NATO and the Integration of Europe. Cambridge: Cambridge University Press.

Shonfield, Andrew. 1969. Modern Capitalism. Oxford: Oxford University Press. 
Sikkink, Kathryn, and Ellen Lutz. 2001. The Justice Cascade: The Evolution and Impact of Foreign Human Rights Trials in Latin America. Chicago Journal of International Law 2:1-33.

Stone Sweet, Alec. 1999. Judicialization and the Construction of Governance. Comparative Political Studies 32 (2):147-184.

- 2000. Governing with Judges. Oxford: Oxford University Press.

- 2004. The Judicial Construction of Europe. Oxford: Oxford University Press.

Vachudová, Milada Anna. 2005. Europe undivided : democracy, leverage, and integration after communism. Oxford ; New York: Oxford University Press.

Voeten, Erik. Forthcoming 2008. The Impartiality of International Judges: Evidence from the European Court of Human Rights. American Political Science Review.

Vogel-Polsky. 1985. National institutional and non-institutional machinery established in the Council of Europe Member States to promote equality between women and men. Strasbourg: Council of Europe, Committee for Equality between Men and Women.

Vogel-Polsky, E. 1967. L'article 119 du traité de Rome peut-il être considéré comme self-executing? Journal des Tribunaux 82e année (4570 April,15 1967):283-287.

Williamson, John. 1990. What Washington Means by Policy Reform. In Latin American Adjustment: How Much Has Happened, edited by J. Williamson. Washington, D.C.: Institute for International Economics,. 